\title{
ALCOHOLISM AND THE POLITICS OF TOTAL PROHIBITION IN TAMIL NADU STATE, INDIA: A HISTORICAL AND SOCIOLOGICAL OVERVIEW
}

\author{
GOPALAKRISHNAN KARUNANITHI
}

\begin{abstract}
The consumption of alcohol in one form or other has prevailed throughout the history of the world. The first half of this paper deals with the sociocultural roots of alcoholism and drinking habits in ancient India, besides discussing its socioeconomic implications and impact on several areas of life. In the second half, it presents the history of the implementation and repeal of total prohibition in Tamil Nadu state against the backdrop of incumbent Dravidian political parties and a series of statewide anti-liquor protests during 2016-2017.
\end{abstract}

KEYWORDS: Alcohol, alcoholism, prohibition, anti-liquor protest.

\section{INTRODUCTION}

The main aim of this paper is to explain drinking practices in ancient India and the socio-economic implications of these in contemporary times, and to justify how the former is an alarming social problem. It also aims to present the relationship between prohibition and politics in Tamil Nadu during the incumbency of Dravidian political parties ${ }^{2}$ and the consequent anti-liquor protests. It is based on a review of some relevant literature on alcoholism and prohibition related to some states in India in general, and Tamil Nadu state in particular. Therefore, this is not an empirical but a descriptive paper, prepared

\footnotetext{
1 Gopalakrishnan Karunanithi is a former Professor of Sociology at Manonmaniam Sundaranar University, e-mail: karunanithig@gmail.com.

2 Dravidian political parties include an array of regional political parties in Tamil Nadu state in India, which trace their origins and ideologies either directly or indirectly to the Dravidian movement patronized by Periyar E. V. Ramasamy.
} 
based on quantitative as well as qualitative methods of analyzing data collected from various pieces of literature, reports, national dailies, and personal interviews.

\section{THE SOCIO-CULTURAL ROOTS OF DRINKING IN INDIA}

From time immemorial, drinking has been associated with the socio-cultural life of people in India. Even now, it is noticeable, especially during cultural events, ceremonies, and dinner parties. However, Pratima Murthy (2015) says that the cultural contexts of alcohol use are associated with socio-political contexts. In ancient India, religion was a determinant of abstinence, whereas the social order was a determinant of drinking. Later on, socio-political contexts became a decisive factor in terms of drinking. However, drinking practices vary according to cultural differences among castes and ethnic groups. For this reason, there are different cultural expressions for drinking at social gatherings. The ancient epics of India, Ramayana and Mahabharata, and other literary works, including Sangam (Tamil) Literature, ${ }^{3}$ include references to drinking, indicating that the habit of drinking was common in Indian society at the time.

Nevertheless, in hierarchically stratified Indian society, drinking in the past was forbidden mostly by high caste groups, whereas it was allowed by middle- and low-caste groups. Accordingly, as indicated by various religious texts, drinking was not associated with the rituals of "great tradition" that have their roots in Vedic rituals mostly practiced by the priestly caste group, i.e., the Brahmins. On the other hand, Robert Redfield (1947) claims that drinking became a part of the rituals of "little tradition" that are rooted in non-Vedic rituals, predominantly practiced by people on the lower rungs of the caste hierarchy. ${ }^{4}$ It can be observed that the practice of offering alcohol to local deities

3 Sangam literature refers to the ancient Tamil literature of South India compiled during the Sangam Age, which was a period of history of ancient parts of Tamil Nadu and Kerala and parts of Sri Lanka approximately spanning the sixth century BCE to the third century CE. It was named after the famous Sangam (organization) academies of poets and scholars centered in Madurai, the second largest city in Tamil Nadu state.

4 Robert Redfield (1947), an American anthropologist, conceived of civilizations in cultural terms as systems of coexisting and interdependent "Great Tradition and Little Tradition". The former is a part of the idea systems - the sciences, philosophy, and fine arts - of the critical and reflective elite, and the latter is a part of the folk arts, lore, and religion of common people. Mckim Marriott and Beals (1955) and Milton Singer (1972), American anthropologists influenced by the studies of Redfield, conducted studies in Indian villages and elaborated the original model of Redfield in the light of data generated from those villages. 
of "little tradition," particularly during festivals in southern districts of Tamil Nadu state, continues to exit even today. It is thus evident that the culture of "little tradition" was generally approving of alcohol consumption, which may therefore be considered a socio-cultural phenomenon or obligation rather than a personal act. This obligation may perhaps be an important factor as regards influencing individual drinking behavior.

However, from the individual point of view, drinking alcohol involves a personal act, because the decision to drink comes from personal choice, not socio-cultural obligations. But, it is also a fact that, one's socio-cultural ties play a significant role in encouraging drinking habits, as well as determining one's stand in relation to an ethical framework. Anthropological accounts of many cultures highlight the congruence of drinking with cultural values such as hospitality, reciprocity, and kinship relations. As regards hospitality, alcohol serves as a means of promoting reciprocal relationships (an important trait of culture) predominantly in folk and tribal societies, but in modern societies as well.

David G. Mandelbaum (1965) considers alcohol to be a cultural relic, because the forms and meanings of drinking alcoholic beverages are culturally defined. Such forms are explicitly stipulated, including the kinds of drink, quantity of intake, times and places of drinking accompanying a ritual, sex and age of drinkers, roles involved in drinking, and role behavior suitable in relation to drinking. However, the meaning of drinking and its relation to other aspects of culture and society are very much implicit. Therefore, drinking habits in a particular society may or may not be a ritualistic act, depending on the context.

\section{MIXED VIEWS ON DRINKING IN ANCIENT INDIA}

There is an indication in an ancient Indian epic, Ramayana, of wine drinking by royal people, as well as a description of heavy drinking in Ayodhya, the birthplace of Rama, hero of the epic. In another ancient Indian epic, Mahabharata, drinking is mentioned in several passages, including a description of the Yadav (shepherd) clan whose downfall was due to in-group fighting while its members were intoxicated by alcohol. The Kshatriyas (kings/warriors) in particular were reported to drink alcohol quite liberally. However, it is also pointed out in Mahabharata that drinking is sinful (Singh and Lal 1979).

In the Vedic period of India (around 1500-1000 BC), the Aryans (this term was used as a self-designation by Indo-Iranians) used to consume soma, a kind of liquor that is referred to in several passages of the Rig Veda (Samhita: 4, 9 and 54). This was served while performing yajna (ritual sacrifice undertaken in 
front of a sacred fire for a specific purpose). Mitra (2016) mentions the drinking of Lord Krishna along with his brother, brother-in-law, and some other family members. Somasundaram and others (2016) indicate that, as presented in Mahabharata, Bharadvaja (a sage in ancient India) offered wine to Bharata (a legendary emperor of India) and his soldiers as a mark of hospitality. In contrast, Manu, the Hindu lawgiver (around 500 BC), prescribed in his work Manusmriti (11: 55) that drinking should be considered an evil and hence be rooted out. Hassan (1922) states that stronger prohibitions regarding the use of alcohol were laid down in the treatises of Hinduism on dharma composed by Apastamba and Gautama. Nevertheless, Courson (2008) says that the Shastras (treatises on the applied sciences), literary works, wall paintings, inscriptions and the like bear witness to the fact that drinking was a very ordinary affair for lower caste groups in India.

It is relevant to learn from Sangam literature how intoxicants were used in ancient Tamil society. For instance, Puranaanooru (56, 216, 235, 290 and 298), an anthology in Sangam literature, describes how drinks formed a part of cuisine and were freely used by all classes of people, irrespective of sex. They were often supplied during social intercourse, and were offered to special visitors and guests by kings and chieftains. In contrast, Thiruvalluvar, a sangam poet and a protagonist of abstinence, expressed the evils of drinking in his universal work Thirukkural (Kallunnaamai: 93). Thus, ancient Tamil and Sanskrit literature in India include both the sanctioning and prohibition of drinking.

It is known that drinking was not a uniform practice among the four varnas (broader divisions of ancient Hindu society). For instance, Sharma (1996) indicates that (as prescribed by some Hindu religious texts with regard to drinking addressed to the four varnas) the Brahmans (priestly class) should abstain from drinking, while the Kshatriyas (king/warrior class) were allowed to drink on certain occasions as part of their military ethos. Relatively fewer restrictions seemed to apply to the Vaisyas (agriculture and trading class) and Shudras (serving class) concerning drinking. Thus, as regards the drinking of different classes of people in ancient India, lenience and abstinence co-existed.

Boesche (2003) refers to the prescription of Arthasastra (an ancient Indian Sanskrit treatise of Kautilya from the fourth century BCE that deals with statecraft, economic policy, and military strategy) in relation to the regulation of alcohol production and sale, including directions for establishing drinking shops. During his time, the Mauryan Empire in India (descendants of mighty rulers who dominated the Indian subcontinent between 322 and $185 \mathrm{BCE}$ ) exercised tight control over the production of alcoholic drinks, and controlled alcohol distribution through government-owned distribution points at which citizens could drink legally. 
Singh and Lal (1979) state that during the Post-Vedic period (between 1400 B.C and 600 B.C) the best known medical treatises written by Charaka and Susruta describe alcohol as a medicine and as a social drink as well. While making a distinction between moderate and excessive drinking, Charaka notes that moderate drinking is "pleasing, digestive, nourishing, and preserves intelligence." He also mentions about alcohol abuse and related problems, including social ones, besides elaborating a specific treatment for alcoholics. It is, however, understood that both the sanctioning and prohibition of drinking have coexisted since Vedic times. This is perhaps the reason why there were no organized Temperance movements in ancient or pre-independence India.

\section{ALCOHOLISM: AN ALARMING SOCIAL PROBLEM IN CONTEMPORARY INDIA}

Setting aside the socio-cultural backdrop and ethical issues related to alcohol, the multiple problems caused by drinking pose a great threat to present and future Indian society. In contemporary times, alcoholism is one of the more alarming social problems both from a personal as well as societal point of view. Alcoholics in India, like their counterparts all over the world, face a series of socioeconomic consequences and health hazards. Civilians in contemporary India are coming to know about various alcohol-related social problems. Although alcoholics understand that drinking is an unhealthy habit from a medical point of view, their attitude to it remains positive. Most manual workers, including sweepers and scavengers in organized as well as unorganized sectors, drink alcohol as a form of relief from fatigue caused by day-long hard work. Moreover, at present, the habit of social drinking is catching up in popularity with drinking coffee or tea. Globally, India is one of the largest markets for alcoholic beverages.

\section{FACTS ABOUT DRINKING AND CONSEQUENT DEATHS IN INDIA}

According to the third National Family Health Survey (NFHS-3, 2005-2006), close to one-third of Indians (mostly adolescents and adults) consume alcohol, and of these, 4-13 per cent of people are regular drinkers. However, a distressing trend amongst boys and girls is emerging: that their initiation to drinking starts 
in late childhood. The WHO Global Status Report on Alcohol and Health (2014) states that, in India, the proportion of those consuming alcohol increased substantially during 2008-2012. It also discloses that, in 2010, over one-third (11 per cent) of the 30 per cent of alcohol consumers were heavy drinkers. The per capita consumption of alcohol by persons over 15 years of age increased from 1.6 liters during 2003-2005 to 2.2 liters during 2010-2012. In comparison, total alcohol per capita consumption in the world's population of over 15 years of age rose from 5.5 liters of pure alcohol in 2005 to 6.4 liters in 2010 (Global status report on alcohol and health 2018). It is thus evident that heavy drinking has been rising at an alarming rate for years.

Another report by the Organization for Economic Cooperation and Development (OECD) in 2015 reveals that, during 1992-2012, per capita consumption of alcohol in India increased by 55 per cent. This is the third highest increase in the world after Russian Federation and Estonia. Globally, out of 2.3 billion drinkers in 2016, more than a quarter of adolescents (26.5 per cent) were consuming alcohol, with only a small difference between boys and girls (Global status report on alcohol and health 2018). Surprisingly, the proportion of women who drink is also on the rise. According to All Indian Institute of Medical Sciences report (Hindustan Times, 20.02.2019), the proportion of women who drink in India (1.6 per cent) is much less than that of their male counterparts ( 27.3 per cent). Relatively more school-going boys than girls in the age group of 14-18 engage in drinking on some occasions. Globally, at the present, the proportion of women who drink is also on the increase (Global status report on alcohol and health 2018).

The proportion of teenagers who drink in India is increasing, mainly due to their increasing positive attitude to drinking. For instance, seeing their parents, relatives, and friends drinking, they get the impression that if drinking is good for the former, it will also be for them. Factors such as association with a family who use alcoholic substances (for instance, "family drinking" in Kerala state in India), surplus pocket money, an absence of parental control, a lack of parent-children interaction, depression due to academic problems, peer group pressure and the like may lead teenagers to drink alcohol. In changing contemporary Indian society, most drinkers, whether adolescents or adults, are neither concerned about ethical issues related to alcohol nor do they attribute importance to the guiding values of their culture.

The WHO Global Status Report on Alcohol and Health (2018) discloses that, worldwide, about three million deaths (5.3 per cent of all deaths) and about 133 million disability-adjusted life years (5.1 per cent of all DALYs) in 2016 were attributable to alcohol consumption. In relation to these data, the proportion of males was twice as great as that of their female counterparts, and victims 
were mostly from the economically productive age group of 25-55. Therefore, the death of millions of alcoholics all over the world has serious economic implications for the years to come. This fact is corroborated by an OECD report (2015) that states that alcohol abuse is the fifth leading cause of death and disability across the world.

The distillers of illicit alcohol in several villages in Tamil Nadu and other states of India are not concerned with the harmful effects of their chemicals on consumers. The spirit brewed illegally by local crude distillers kills some consumers immediately after drinking. For instance, in Kerala state, several people have died on different occasions after drinking hooch, an inferior alcoholic beverage illegally brewed mostly in villages and sold by bootleggers. Similarly, in Tamil Nadu and other states, several deaths have been reported at different times due to the consumption of illicit liquor. As many as 1,699 people died in India in 2014 after consuming harmful/illicit liquor, a notable increase compared to 2013 data. In 2015, the consumption of illegally brewed liquor claimed more than 100 lives in the Malwani area in Mumbai city. According to figures compiled from the National Crime Record Bureau (2013), during the last decade (2005-2014) Tamil Nadu state registered 1,509 deaths due to the consumption of harmful liquor. In the same period, for the same reason, Karnataka and Punjab states witnessed 1421 and 1364 deaths respectively, while 843 deaths occurred in Gujarat state.

Further, in the states of Uttar Pradesh and Utterkand in India, over 100 people died due to toxic alcohol (The Hindu, 13. 02. 2019). Similarly, in Assam state, the recent death toll due to hooch touched 155 (The Hindu, 25. 02. 2019). It is reported in The Hindu (13.02. 2019) that "India remains among the countries with a high number of alcohol-related deaths, with poor governance, corruption and distorted policies contributing to such periodic tragedies." Numerous instances of toxic alcohol poisoning have been mainly due to the lack of affordable liquor for the poor, and an increase in the cheap brews controlled by criminal gangs.

\section{SOCIOECONOMIC IMPLICATIONS}

Habitual drinkers of the working class in India may have serious economic problems because more or less half of their earnings often go to wine/arrack shops. Their ability and vigor are reduced significantly, to the extent of decreasing their productivity (Institute of Alcohol Studies, 2014). For instance, in Nairobi, most employees demonstrate irregular work attendance, low productivity, poor health, and safety risks because of alcoholism (Kaithuru - Stephen 2015). 
Consequently, their low earnings do not provide their family members with one full meal a day. In such a situation, their wives and children are often forced to do low paid and mostly hazardous jobs to sustain their livelihoods. The early employment of millions of children as full-time workers is a violation of their right to education.

Moreover, heavy drinkers are subject to personal disorganization. This may lead to the disregard of families and their succumbing to health-related problems. Ultimately, this will result in the disintegration of families, leading to the situation in which helpless wives and children will be forced to struggle for their survival. In the absence of parental control, children may turn into juvenile delinquents and later on become criminals. Once they are absorbed into criminal gangs, they become oriented around a criminal sub-culture, which operates counter to the dominant culture of society. As drinking is one of the traits of this sub-culture, they may become habitual drinkers sooner or later.

\section{Alcohol and violence}

According to the WHO Global Status Report on Alcohol and Health (2004), most violent incidents occur owing to the influence of alcohol. The association between the two factors has been confirmed by various studies outside India (Shepherd 1998; Budd 2003; Richardson et al. 2003; Finney 2004). Similarly, some studies conducted in India disclose that a majority of violent incidents inside or outside the home are attributable to habitual drinking (Vijayanath Tarachand 2011; International Center for Research on Women 2000; Begum et al., 2015). In the same way, there is a close correlation between alcohol use and domestic violence in terms of wife battering, sexual harassment, child abuse, and the like. The WHO (Intimate Partner Violence and Alcohol Fact Sheet Website) reports that alcohol drinking increases the occurrence and severity of domestic violence. Collins and Spencer (2002) find that an increase in domestic violence is often related to the fact that both spouses are habitual drinkers. According to a WHO study (2004), every third violent husband is a drinker who is responsible for most of the violent incidences that occur when partners are under the influence of alcohol. McClelland and Teplin (2001) disclose that, in the United States, close to 40 per cent of police calls are due to domestic violence caused by alcoholic husbands. Studies on partner violence indicate that this sort of violence is more severe when men are intoxicated by alcohol (Leonard 2005; McKinney et al. 2010). Some other studies point out that partner violence is typically severe when both partners happen to be habitual drinkers (Thompson - Kingree 2006; Stanley 2008). Another study (Marlene Berg et al. 2010) claims 
that alcoholic husbands are responsible for causing domestic violence. Men play a predominant role in this (Fazonne et al. 1997), while women's role is relatively smaller (Kaufman - Strauss, 1987). The alcohol-related death of husbands turns many young women into widows. Many women of the working class are subject to physical harassment at the hands of their drunkard husbands, and hence they invariably support a ban on liquor. There is, therefore, a strong correlation between drinking on the one hand and physical violence between life partners on the other that eventually results in the cessation of marital bonds.

The following episode, based on a case study conducted in the west of Tirunelveli district in Southern Tamil Nadu state in 2007, describes wife battering under the influence of alcohol (Karunanithi, 2010).

In a village situated in the west of the Tirunelveli District of Tamil Nadu state, a drunkard husband used to quarrel with his wife almost every day for trivial reasons, but her refusal to give him money for drinking seemed to have been the main cause. He never cared about the presence of his young son and daughter while beating her. They were unable to do anything except to sympathize with their helpless mother. One night, in their absence, the drunkard husband hit her brutally with a strong wooden pole. As she received severe head injuries, she had heavy blood loss and ultimately succumbed to her injuries. In order to escape responsibility for this murder, he poured kerosene on her body and burnt it beyond recognition. As a pretext, he shouted that she had committed suicide. Afterwards, he was remanded in custody, charged with the murder of his wife. After a trial of some months, the court ordered him to undergo a double sentence of life imprisonment. Though the children were then placed under the care of their maternal grandparents, the loss of their mother affected them very much.

In support of this, a recent analysis by the National Family Health Survey-3 reveals that there is an association between violence against women and the drinking habits of their husbands.

\section{Other effects of alcohol}

In workplaces, the negative impact of alcohol consumption on workers includes early death, injuries, fatal road accidents, damage to equipment, frequent absenteeism, a lack of punctuality, a loss of efficiency, loss of production, low morale, weak productive relations, and the like. For instance, according to 
Indian industry association sources, 15-20 per cent of absenteeism and about 40 per cent of accidents at workplaces are due to alcohol consumption (Saxena, et al., 2003). Moreover, most road accidents that result in casualties are due to drinking (Cherpitel et al., 2009).

Similarly, customary drinking is one of the major causes of suicide, which is increasing. A study by Maurizio Pompili et al. (2010) shows that drinking consistently precipitates suicidal tendencies. Hence, alcoholics are at increased risk of suicide while drinking (Frances et al., 1987; Richardson et al., 2003; Brady, 2006). Some other studies claim that Alcohol Use Disorder (AUD) significantly increases the risk of suicidal thoughts, suicide attempts, and ultimately, successful attempts at suicide by alcoholics. The association between alcohol use on the one hand and suicide and homicide on the other is evident (Lester, 1995; Gruenewald et al., 1995). Thus alcoholism is an important predictor of suicide and greatly responsible for premature deaths.

In one way or another, excessive drinkers are typically associated with criminal behavior. The U.S. Department of Justice claims that a majority of criminal offenders are under the influence of alcohol while committing crimes. The Federal Research Program authorized by the U.S. Congress confirms that alcoholism is an important factor in about 40 per cent of homicides.

\section{Alcohol-related problems confronting women}

In millions of laboring families in India, due to the presence of drunkard husbands, women have become the main breadwinners and started attempting to maintain the balance between household income and expenditure. A majority of marginalized women in rural India are members of Self-Help Groups (SHGs) organized mostly with the support of local NGOs to develop and empower women. These groups orient them in terms of financial management, particularly in relation to saving for the future and accomplishing economic empowerment, which is a prerequisite of their social and political empowerment. A case study about a poor rural woman engaged in beedi (local cigarette) making conducted in the west of Tirunelveli district in Southern Tamil Nadu state in 2009 explains how a drunkard husband created challenges for his wife and how she overcame those challenges with the support of a SHG (Karunanithi, 2010).

I was primarily a beedi worker and a mother of three girl children aged from 10-18. Since my husband was addicted to alcohol, he was in no way helpful to us economically or morally. My earnings were the major source for sustaining the livelihood of my family. However, by force, 
he often used to get a sizeable portion of my earnings for drinking. At one point in time, from compulsion, I borrowed money from a local moneylender at a high interest rate. After some time, I found it very difficult to pay back the interest.

In this circumstance, I necessarily had to compel my first daughter, who was studying at secondary school, to roll beedis to increase our income in order to meet our basic needs, besides repaying the interest. Subsequently, my second daughter, who was studying at primary school, also fell into the same line of work. Unfortunately, both of them were denied education due to no fault of their own. But, fortunately, I joined a SHG formed in my village by a local NGO. Over a short period, all members were able to mobilize a sizeable corpus fund for the group by making a weekly contribution.

As a result, I availed myself of financial support in terms of a few thousand INR at nominal interest from the group corpus fund, besides receiving my share of bank microcredit taken out by my group for entrepreneurial activities. With this, I cleared my debt and was relieved from the fetters of the moneylender. Although I had deprived the right of my two daughters to education, I decided to allow my third daughter to pursue collegiate education. Meanwhile, I managed to get my first daughter married, and to guide my second one to join other SHG. With the help and support of the members of my group and the NGO, I somehow set right the behavior of my husband and also made him assume several family responsibilities. Moreover, I am now heading my household and making decisions relating to all our domestic affairs in consultation with my group members.

At present, in Tamil Nadu state, the proportion of women-headed households in rural areas is increasing. This is perhaps due to the fact that their husbands are drunkards and reckless. As the former earn more than their husbands do, the household economy is mostly based on the earnings of their wives. Consequently, they become the main breadwinners in their households. However, in many households a day-to-day problem that the former face is none other than the fact that their husbands assault them to get money for drinking. In rural areas, women, in spite of their major contribution to household income, are often subject to physical harassment by their drunkard husbands. However, it is the moral responsibility of the government to tackle alcohol-related problems in order to solve the numerous problems caused by drinking and restore harmony to millions of families. It is therefore relevant here to discuss the stand of the Tamil Nadu government over the years as regards the introduction of a total ban on liquor. 


\section{PROHIBITION AND POLITICS IN TAMIL NADU STATE}

Prohibition and its relation to public elections have been a part of Tamil Nadu state politics over several decades, while Tamil Nadu state continues to be a significant market for liquor in India. The logic and hypocrisy of prohibition lies in the fact that it significantly helps politicians obtain the electoral support of women. Moreover, prohibition has become the moral responsibility of the government in terms of saving people from drink-related tragedy. However, the huge revenue required by the government from liquor sales is equally important. Therefore, the immediate task is how to moderate the socioeconomic consequences of alcoholism.

In Tamil Nadu state, the demand for prohibition dates back to the late 1930s. The Madras Presidency's Chief Minister, C. Rajagopalachari, introduced total prohibition in Salem (a city situated in western Tamil Nadu) in 1937 on an experimental basis, which was enforced later across the state. In 1948, the then chief minister of Madras State, Omandur Ramasamy Reddiyar, introduced total prohibition, which remained in force until 1970. In 1971, the ruling Dravida Munnetra Kazhagam (DMK, an offshoot of the Dravidian Movement in Tamil Nadu started in 1916) lifted the ban, but in the same year Rajagopalachari met the then chief minister, M. Karunanidhi, to plead against lifting prohibition on the grounds that drinking would adversely affect future generations (The Hindu, 22. 07. 2015). Consequently, the same government enforced total prohibition in 1974. Later on, the government of the ruling All India Anna Dravida Munnetra Kazhagam (AIADMK, an offshoot of DMK) lifted the ban in 1981, allowing the sale of arrack and toddy as well. In 1983, it created the Tamil Nadu State Marketing Corporation (TASMAC) to sell liquor throughout the state. This corporation has ironclad control over the distribution of liquor in the state. Subsequently, the government moved further to tighten TASMAC's grip over liquor sales (through 6,798 retail outlets) in the state due to its potential to bring in huge revenue. As a result of this, during 2010-2011 it earned 180,000 million INR (Prabhakar, The Economics Times, 2013).

Again in 1987, the ruling AIADMK government introduced a ban on liquor because of a series of deaths caused by the consumption of illicit liquor. After returning to power in 1989, the DMK government reinstated the policy of selling arrack and toddy in 1990. In this period, liquor in polythene packets was sold at cheaper prices. But the AIADMK government overturned this after coming to power again in 1991 in order to fulfill an election promise to ban the sale of arrack and toddy. However, in 2002, the AIADMK government permitted the sale of cheap liquor through TASMAC for the reason that Indian Made Foreign Liquor (IMFL) was beyond the reach of poor people. This change brought the 
government huge revenue during 2014-2015 (The Indian Express, 19. 04. 2016). When AIADMK started their election campaign on April 9, 2016, the then Tamil Nadu chief minister announced that the government would implement prohibition in a phased manner if the party were voted into power. On the other hand, DMK in its election manifesto promised to introduce total prohibition to the state. When AIADMK came to power in 2016, the then chief minister, as announced during election time, ordered the closing down of 500 TASMAC outlets in the first phase. Later on, the newly appointed chief minister from the same party ordered the closing down of 500 more liquor outlets in February 2017. Even after the closure of 1000 outlets, 5262 outlets are in operation at present. This is perhaps why, during Diwali festival time in November 2018, TASMAC earned 33 million INR, which shows that alcohol consumption in the state is increasing. Nevertheless, the government has promised to implement total prohibition in a phased manner.

The sequential attempts of the Tamil Nadu government to enforce as well as lift prohibition show one thing clearly: that the ruling Dravidian Parties (DMK and AIDMK) have drawn prohibition into politics. These two parties have alternated between a policy of total prohibition and total indulgence for over half a century. Consequently, a large section of population, mostly poor and lowincome groups have become addicts to alcohol, besides spreading this addiction to a sizeable number of adolescents. Although both parties have already promised to introduce total prohibition, both of them are equally interested in generating revenue from the liquor business. The TASMAC happens to be an especially useful tool for influencing their potential voting bloc in terms of permitting free access to alcohol. Therefore, permanent and total prohibition in Tamil Nadu state is doubtful in future.

\section{PROHIBITION IN SOME OTHER STATES OF INDIA}

Alcohol consumption was prohibited in Gujarat state in 1958 to honor Mahatma Gandhi, who made repeated appeals to the people of India to abstain from trading and drinking alcohol. Considering his appeal, the Constitution of India included Article 47 in the Directive Principles of State Policy, which gives the right to states to introduce prohibition. But, in contemporary Gujarat state, alcohol consumption has been rampant. Rahi Gaikwad (The Hindu 31.08.2014) says that, according to a police source, a "bootlegging modus operandi" has technically been developed in such a way as to supply illicit alcohol clandestinely. Accordingly, illicit liquor from some states is being supplied to 
Gujarat state surreptitiously. It is thus clear that total prohibition in this state has proven to be unsuccessful. Additionally, total prohibition is presently in operation in three states in India (Bihar, Nagaland and Manipur) and an island (Lakshadweep). Though these states and a few more states (Kerala and Andhra Pradesh) have banned alcohol either totally or partially, they continue to face the problem of the illegal and secret supply of alcohol. For instance, after the proclamation of a total ban on the sale and consumption of alcohol on 1 April 2016 by the Bihar government, over 71,000 people in the state were arrested under the new liquor law. The authorities concerned had seized 852,452 liters of India Made Foreign Liquor, 560,770 liters of domestic brew, and 11,617 liters of beer by the first quarter of 2017 (Firstpost, 02. 02. 2019).

It is important to mention that several states in India have been experiencing anti-liquor protests in the recent past. Tamil Nadu state in particular has been witnessing similar protests since July 2015 associated with a demand for total prohibition.

\section{ANTI-LIQUOR PROTESTS IN CONTEMPORARY TAMIL NADU STATE}

This sort of protest, or Temperance movement, was not reported in earlier periods of Tamil Nadu state because the proportion of alcohol-related crimes and violent incidents including domestic violence were insignificant. In contrast, since independence, such sorts of crimes and incidents in the state have multiplied disproportionately, necessitating anti-liquor protests all over the state. Here the aim is to focus on a selection of such protests in contemporary Tamil Nadu state. In August 2015, there were a series of demonstrations against alcohol by civilians, including students, across the state. During these anti-liquor protests, several opposition parties united to call for a statewide bandh (a general strike) to press the AIADMK ruling party to implement total prohibition. Local parties in the state such as the Paattali Makkal Katchi (PMK) and the Marumalarchi Dravida Munnetra Kazhagam (MDMK, an offshoot of DMK) were consistent in demanding total prohibition. They often protested against the setting up of new TASMAC outlets, as well as new Elite TASMAC shops (exclusive outlets for imported liquor). Here three anti-alcohol protests in the state are worth describing.

First, in August 2015 the residents of Kalingapatti (a village in Tirunelveli district of southern Tamil Nadu state) tried to lock down a TASMAC outlet situated in the village. A protest aimed at closing down the outlet was led by the 
aging mother of MDMK party president. When villagers and workers from this party and Viduthalai Chiruthaigal Katchi (VCK- Liberation Panther Party) were trying to ransack an outlet, police resorted to a lathi charge and fired tear gas.

Second, the situation became acute when Sasi Perumal, a Gandhian activist, died on 31 July 2015 during a protest in the Kanyakumari district of southern Tamil Nadu state while demanding the closure of a liquor shop (The Indian Express, 01. 08. 2015). Consequently, protests erupted across the state targeting TASMAC shops. Protesters forced the owners to shut down their shops in many parts of the state, and in some places they ransacked and vandalized.

Third, during this protest, police arrested Kovan, a folk singer and a member of Makkal Kalai Iyakkam (People's Arts Movement) on 30 October 2015, who through his songs criticized the government for its way of earning revenue through liquor. He was arrested on sedition charges, with the claim that his songs criticized the state government. Most of the opposition party leaders rallied behind him and sought his immediate release. Anti-liquor protests in Tamil Nadu state are also, in one way or another, influenced by a similar protest in the 1990s spearheaded by rural women in Andhra Pradesh, which stunned the government as well as the ruling party (Kancha Ilaiah, 1992: 2406-2408).

In addition to this, similar protests have been organized in several parts of the state. However, women are typically at the forefront of protests against alcohol consumption, as they have experienced its dreadful consequences over the years. For instance, a group of women in Anaikatty village in Coimbatore district of western Tamil Nadu state organized an anti-liquor agitation on 1 April 2017 in a Gandhian way (non-violent), demanding the closure of a TASMAC shop located there. After three month of peaceful agitation, they succeeded (Sudhir, Firstpost, 27. 04. 2017). On 4 April 2017 there was a grave scuffle between protesters and owners of a TASMAC outlet in Serinchamalai village in the same district. When a higher police official tried to intervene, he was assaulted by the protesters (Rakesh Mehar, The News Minute, 26. 04. 2017). On 23 April 2017, a group of 28 persons, including 17 women, vandalized a newly opened TASMAC shop in Mecheri town in Salem city in Tamil Nadu state. For a week, they protested against the move to shift the location of the shop even after the issuance of a court order. Despite their peaceful agitation, the event of the shop opening turned the protesters into vandals who damaged the shop, resulting in their immediate arrest (Sudhir, Firstpost, 27. 04. 2017).

National and state-level political parties supported the protests by stressing the ban on liquor. Importantly, in the wake of the Tamil Nadu Assembly election in May 2016, the prohibition agenda was ranked in first place on the list of election manifestos released by all political parties. It was figured particularly prominently in DMK party's election declaration, which proclaimed that when 
they came to power, the first signature of the incoming chief minister would be on a law implementing total prohibition with immediate effect. On the other hand, the AIADMK party promised to introduce total prohibition in a phased manner if elected to power.

Whichever party (either DMK or AIADMK) comes to power, it prefers to lift the ban on liquor to generate more revenue due to its facing a financial crunch. But, during election time, prohibition becomes a rightful mantra for these political parties that are deployed to attract the attention of women voters. Thus, prohibition becomes their seasonal game. The act of enforcing a total ban on liquor would result in the closure of most of the subsidy programs of the government. Therefore, an attempt to regulate sales of liquor may perhaps be a substitute for total prohibition. However, the application of this regulation depends on the government's stand in terms of maintaining a balance between revenue and development.

However, the question that needs to be addressed now is whether total prohibition would result in an illegal supply of hooch or illicit alcohol. Undoubtedly, the answer is yes if the state fails to define decisive as well as deterrent measures to stop this. Otherwise, the state would experience regular hooch-related tragedies, mostly involving poor sections of the population. For instance, some rural unemployed youth are likely to take to bootlegging, which is associated with two problems: corruption and smuggling. In other words, bootleggers have to pay bribes to political leaders and officials to encourage them to overlook their illicit brewing and illegal transportation of alcohol. Shiv Viswanathan (The Hindu, 11. 04. 2016) holds a similar view as regards the situation in Kerala state, where bar owners reported that they were paying huge sums of money as bribes to various political leaders to permit them to run their businesses without problems.

Presumably, total prohibition in Tamil Nadu state is not possible until the distillery units supported by the DMK and AIADMK leaders ${ }^{5}$ are closed down. In a similar vein, Justice Sandru, a former Madras High Court Judge, points out that the release of election manifestos by the Dravidian political parties is a form of election stunt, because both parties have experienced the pros and cons of introducing as well as lifting prohibition because they have alternatively ruled Tamil Nadu state since 1967. It is, therefore, implicit that they do not want to stick to a policy of total prohibition. Venkatesh Athreya, an economist, while accepting the impossibility of implementing total prohibition, indicates that it

5 According to the TASMAC website, there are currently 11 distilleries and 7 breweries in Tamil Nadu state. Some of them are supported by the DMK party and others by the AIADMK party (Sameera Ahmed, The New Minute, 06.08. 2015). 
is possible for the present ruling AIADMK party to prolong the introduction of total prohibition without end, even after having committed to introduce total prohibition in a phased manner (The Hind [Tamil], 12. 04. 2016).

Public opinion in Tamil Nadu state is that, since the government has become intoxicated by alcohol revenue, it will not implement total prohibition. Moreover, distilleries and breweries are supported by strong political leaders of DMK and AIADMK and their close relatives.

Therefore, whichever of these parties comes to power, the possibility of introducing total prohibition will remain a daydream. This may be true of other states because they also seek revenue even in difficult situations. For instance, after forty days of lockdown due to COVID-19, liquor shops across various states in India were opened from May 4 2020. Long queues marked the reopening of liquor vending outlets in all places, with no concern about social distancing. Moreover, protests were held in several places against the reopening of such liquor outlets. The question now arises, why did the government re-open liquor shops in this critical situation? The answer is that liquor sales are one of the major sources of revenue for states. As most of the states are under pressure to raise funds to deal with COVID-19, they did so with disregard for the other drawbacks.

\section{CONCLUSION}

In spite of the fact that more than one-third of tax revenue comes from the TASMAC, the present ruling AIADMK party in Tamil Nadu state has committed to enforcing total prohibition in a phased manner. Nevertheless, earlier experiments with prohibition in the state show that the quick or gradual closure of liquor shops results in the emergence of an underground trade in illicit alcohol. In such a situation, habitual drinkers visit local bootleggers or liquor shops in Pondicherry (nearby union territory) by crossing state borders. Moreover, a total ban would necessarily require the government to face an uphill task of providing alternate employment to those presently employed in more than 5200 TASMAC shops all over the state, and more importantly, generating an alternate source of revenue.

Despite these shortcomings, the ruling AIADMK appears to be determined to implement the policy it committed itself to in 2016 election manifesto with respect to total prohibition, even in consideration of the future of several million families in the state. It is perhaps the right time to enforce a total ban on liquor step by step, because the state is getting ready for elections to the assembly in 2021. In this task, all political parties, public-, civil service- and similar bodies 
may extend their full support to the government. Eventually, this may save a large section of population in the state from drowning in alcohol and becoming spoiled.

\section{REFERENCES}

Begum, S. - Donta, B. - Nair, S. - Prakasam, C.P. (2015), "Socio-demographic factors associated with domestic violence in urban slums, Mumbai, Maharashtra, India", Indian Journal of Medical Research, Vol. 141, pp. 783788, DOI: 10.4103/0971-5916.160701.

Berg, M. J. - Kremelberg D. - Dwivedi P. - Verma S. - Schensul J. J. - Gupta K. - Chandran D. - Singh S. K. (2010), "The Effects of Husbands' Alcohol Consumption on Married Women in Three Low-Income Areas of Greater Mumbai”, AIDS and Behaviour, Vol. 14 (Supplement 1), pp. 126-135, DOI: 10.1007/s10461-010-9735-7.

Boesche, R. (2003), The first great political realist: Kautilya and his Arthashastra, Lanham, Lexington Books.

Brady, J. (2006), "The association between alcohol misuse and suicidal behavior", Alcohol and Alcoholism, Vol. 41, No 5, pp. 473-478, Epub 2006 Aug 4.

Budd, T. (2003), Alcohol-related assault: findings from the British Crime Survey, Home Office Online Report 35/03, London, Home Office.

Cherpitel, C. J. - Borges, G. - Giesbrecht, N. - Hungerford, D. - Peden, M. Poznyak, V. - Room, R. - Stockwel, T. (eds.) (2009), Alcohol and Injuries Emergency Department Studies in an International Perspective, WHO.

Collins, J. J. - Spencer, D. L. (1999), Linkage of Domestic Violence and Substance Abuse Services, Research in Brief, Executive Summary.

Courson, W. (2008), "Alcohol: an Ayurvedic view", Light on Ayurveda Journal, Vol. 7.

Fazonne, P. - Holton, J. - Reed, B. (1997), Substance Abuse Treatment and Domestic Violence. Treatment Improvement Protocol (TIP) Series 25, US Department of Health and Human Services.

Finney, A. (2004), "Alcohol and sexual violence: key findings from the research", Finding 215.

Firstpost, 02. 02. 2019; 27.04. 2017.

Frances, R. J. - Franklin, J. - Flavin, D. K. (1987), "Suicide and Alcoholism", The American Journal of Drug and Alcohol Abuse, Vol. 13, No 3, pp. 327-341, published online: 07 July 2009.

Gaikwad, R. (2014), The Hindu, August 31, 2014. 
Gruenewald, P. J. - Ponicki, W. R. - Mitchell, P. R. (1995), "Suicide rates and alcohol consumption in the United States, 1970-89", Addiction, Vol. 90, No 8 (August), pp. 1063-1075, DOI: 10.1046/j.1360-0443.1995.90810635.x.

Hassan, B. (1922), The drink and drug evil in India. Madras, Ganesh.

Ilaiah, K. (1992), "Andhra Pradesh's Anti-Liquor Movement", Economic and Political Weekly, Vol. 27, No 45 (November), pp. 2406-2408.

Institute of Alcohol Studies (2014), Alcohol in the workplace.

International Center for Research on Women (2000), Domestic Violence in India -A Summary Report of a Multi-Site Household Survey. International Center for Research on Women, Washington D. C .

Kaithuru, P. N. - Stephen, A. (2015), "Alcoholism and its Impact on Work: A case of Kenya Meteorological Station, Nairobi", Journal of Alcoholism and Drug Dependence, Vol. 3, No 2, pp. 2-4, DOI: 10.4172/23296488.1000192.

Karunanithi, G. (2010), "Self-Help Groups as Social Capital Empowering Women and Promoting Local Development: The Tamil Nadu Experience", in: G. Karunanithi and M. Ramakrishnan (eds.) Social Capital and Social Resources: Concept and Reality, Tirunelveli, M.S. University Publication Division, pp. 27-62.

Kaufman, K. G. - Strauss, M. A. (1987), “The 'Drunken bum' Theory of Wife Beating", Social Problems Vol. 34, No 3, pp. 213-230, DOI: Org/10.2307/800763.

Leonard, K. E. (2005), "Alcohol and intimate partner violence: when can we say that heavy drinking is a contributing cause of violence?" (Editorial), Addiction, Vol. 100, No 4 (April), pp. 422-425, DOI: org/10.1111/j.13600443.2005.00994.x.

Lester, D. (1995), "The association between alcohol consumption and suicide and homicide rates: a study of 13 nations", Alcohol and Alcoholism, Vol. 30, No 4 (July), pp. 465- 468, DOI: Org/10.1093/oxfordjournals.alcalc.a045759.

Mandelbaum, D. G. (1965), "Alcohol and Culture", Current Anthropology, Vol. 6, No 3, pp. 289-293, https://www.jstor.org/stable/2739922.

Manusmriti: 11: 55.

Marriott, M. (1955), "Little Communities in an Indigenous Civilization", in: M. Marriott (eds.), Village India - Studies in the Little Community, Chicago, Chicago University Press, pp. 171-222.

McClelland, G. M. - Teplin, L. A. (2001), "Alcohol intoxication and violent crime implications for public health policy", American Journal of Addiction, Vol. 10, s1, pp.70-85, DOI: 10.1080/10550490150504155.

McKinney, C. M. - Caetano, R. - Rodriguez, L. A. - Okoro, N. (2010), “Does alcohol involvement increase the severity of intimate partner violence?", 
Alcoholism, clinical and experimental research, Vol. 34, No 4, pp. 655-658, DOI: 10.1111/j.1530-0277.2009.01134.x.

Mitra, R. (2016), "Spirituous drinks in ancient India", Journal of Asiatic Society of Bengal, Vol. 43, (1873), pp.1-23.

Murthy, P. (2015), "Culture and alcohol use in India", World Cultural Psychiatry Research Review, Vol. 10, No 1, pp. 27-39, Corpus ID: 43074458.

National Crime Record Bureau (2013) Report.

National Family Health Survey 3 (2005-2006) Report.

Organization for Economic Cooperation and Development (2015) Report.

Pompili, M. - Serafini, G. - Innamorati, M. - Dominici, M. - Ferracuti, S. Kotzalidis, G. D. - Serra, G. - Girardi, P. - Janiri, L. - Tatarelli, R. - Sher, L. - Lester, D. (2010), "Suicidal Behaviour and Alcohol Abuse", International Journal of Environmental Research and Public Health, Vol. 7, No 4), pp. 1392-1431, DOI: 10.3390/ijerph7041392.

Prabhakar, B. (2013), "Why Tamil Nadu is the most daunting liquor market in India?" The Economics Times, 10 Feb.

Puranaanooru: 56, 216, 235, 290, and 298.

Redfield, R. (1940), "The Folk Society", The American Journal of Sociology, Vol. 45, No. 5, pp. 731-742, DOI: org/10.1086/218449.

Richardson, A. - Budd, T. - Engineer, R. - Phillips, A. - Thompson, J. - Nicholls, J. (2003), "Drinking, Crime and Disorder", Findings 185, Communication Development Unit, London, Home Office.

Rig-Veda: Samhita: 4, 9 and 54.

Saxena, S. - Sharma, R. - Maulik, P. K. (2003), "Impact of Alcohol use on poor families: a study from North India", Journal of Substance Use and Misuse, Vol. 8, No 2, pp. 78-84, DOI: org/10.1080/1465989031000109798.

Sharma, H. K. (1996), "Socio-cultural perspective of substance use in India", Substance Use Misuse, Vol. 31, No 11\&12, pp. 1689-1714, DOI: org/10.3109/10826089609063997.

Shepherd, J. (1998), "Emergency room research on links between alcohol and violent injury", Addiction, Vol. 93, No 8, pp. 1261-1263, DOI: 10.1080/09652149835080.

Singer, M. (1972), Anthropological Approach to Indian Civilization, New York, Praeger Publishers.

Singh, G. - Lal, B. (1979), "Alcohol in India: a review of cultural traditions and drinking practices", Indian Journal of Psychiatry, Vol. 21, No 21, pp. 39-45.

Somasundaram, O. - Raghavan, D. V. - Murthy, T. (2016), "Drinking habits in ancient India", History of Psychiatry, Vol. 58, No 1, pp. 93-96, DOI: 10.4103/0019-5545.174396. 
Stanley, S. (2008), "Interpersonal violence in alcohol complicated marital relationships (a study from India)", Journal of Family Violence, Vol. 23, No 8, pp. 767-776, DOI: 10.1007/s10896-008-9202-7.

The Hindu, 22. 07. 2015; 11.04.2016; 13. 02. 2019; 25. 02. 2019.

The Hindu (Tamil), Prohibition, 12. 04. 2016.

The Indian Express, 01. 08. 2015; 19. 04. 2016.

The New Minute, 06.08. 2015; 26. 04. 2017.

Thirukkural: Kallunnaamai: 93.

Thompson, M. P. - Kingree, J. B. (2006), "The roles of victim and perpetrator alcohol use in intimate partner violence outcomes", Interpersonal Violence, Vol. 21, No 2, pp. 163-177, DOI: 10.1177/0886260505282283.

Vijayanath, V. - Tarachand, K. C. (2011), "Alcohol and Crime Behaviour", Journal of Indian Academy of Forensic Medicine, Vol. 33, No 3, pp. 241-247, ISSN 0971-0973.

Wikipedia: https://en.wikipedia.org/wiki/Alcohol_prohibition_in_Tamil_ Nadu/last access: 20.02. 2020.

WHO Global Status Report on Alcohol and Health, 2004, 2014 \& 2018.

WHO (no date): Intimate Partner Violence and Alcohol Fact Sheet, https:// www.who.int/violence_injury_prevention/violence/world_report/factsheets/ fs_intimate.pdf/ last access: 09162019. 
